\title{
How to Make Employee Work? Figuring Out What Factors Cause It
}

\author{
Tri Yuni Hendrowati \\ STKIP Muhammadiyah Pringsewu \\ triyunihendrowati@stkipmpringsewu-lpg.ac.id
}

\author{
Novita Eka Tristiana \\ STKIP Muhammadiyah Pringsewu \\ novita@stkipmpringsewu-lpg.ac.id
}

\begin{abstract}
To determine factors that cause employees of STKIP Muhammadiyah Pringsewu have good commitment is very important, as its influence to the development of this campus. There are many factors that influence work commitment, yet in this study, the researchers focused on interpersonal communication, work motivation, and the employee's characters. The research questions formulated in this study are: What factors influence the work commitment of the employee of STKIP Muhammadiyah Pringsewu? Among those factors, which factor has more influence on the employees work commitment? And how the dominant factor influences the employees work? A descriptive qualitative research used in this study. The interest population in this study was all the employees of STKIP Muhammadiyah Pringsewu Lampung across various units and divisions since this was the employees under study. This study population comprised a total of 66 from all of the units or division, namely consist of 26 staffs and 40 the lecturers as staff. The sampling technique used in this study was stratified random sampling with 40 samples. The data collection instrument used was the questionnaire developed by the researchers, especially for this study. The research finding shows that interpersonal communication, work motivation, and the employees' character influence the work commitment of the employees of STKIP MPL. From those factors, work motivation gives more influence; meanwhile character is the dominant factors on the employees' work commitment.
\end{abstract}

Keyword: interpersonal communication, work motivation and employees' character, and work commitment

\section{INTRODUCTION}

STKIP Muhammadiyah Pringsewu Lampung (STKIP MPL) envisions an excellent and Islamic Educational Institution for Staff of Education (LPTK). There are 5 primary points that developed by STKIP MPL in achieving those vision, such as: education, research, community service, Al-Islam Kemuhammadiyahan Service and Organization service. To achieve the vision, employees' work performance especially in organization service division is a pivotal point. The employee of STKIP MPL consists of staff and lecturers who also have the duty as staff. This means that the staff only focuses on their work as administrative personnel in the unit or division in STKIP MPL. Meanwhile, the lecturers who also have the duty as staff are not only responsible to perform the 4 obligations of lecturer, such as: teaching, researching, conducting the community service, and implementing AIK (Islam and Muhammadiyah teaching) but also in charged in their unit or division.

It means that both of staffs and lecturers share the same duty as staff, they have the similar task and responsibility in the organization of STKIP MPL related to their job description. The task and responsibility can be well managed if both of parties have the similar vision as the institution. So, they need to work well and have good commitment to achieve the Vision of STKIP MPL. [1] declare that there are several factors may affect organizational commitment, namely: (1) psychological and social aspect that includes the defence of the ego, individual motivation, and peer pressure; (2) organization that includes communication and the internal situation of organization; (3) characteristic of the project; and (4) contextual. Therefore, the ability for having good social relationship among the employees is very vital; this can be proved by self-controlling of ego, managing motivation and peer pressure. A good relationship is build through taking part in organization that supported by fluent communication. Moreover, a good cooperation among employees also needed in succession to achieving the institution's vision in the contextual condition. Those ideas also supported by Felicia in [7] who asserted that the success of achieving the organization's objectives are basically determined by the ability and communication skills of leaders of the organization.

Hence, the leader in the organization should be able to draw up the vision and mission of this organization. In order to share planning, a leader should communicate his idea both in oral and written form. Oral communication can be achieved through seminar, meeting, and ceremonial event in organization; then, written is in the form of regulation that should be obeyed by all of the people in the organization. Another factor beside work commitment in achieving the organization vision is leader's interpersonal communication skills, which is important to improve the member attachment to an organization.[2] Declares interpersonal communication as "conveying message from one individual (the sender) to another (the receiver) through verbal and non-verbal signals the message being the information that is being conveyed from the sender to the receiver" and in addition asserts that interpersonal communication at all times take 
place within a particular context". Meanwhile, [3] declare motivation means to be moved to do something. Therefore, someone is energized or acted towards an end is considered motivated, whereas, a person who feels no inspiration to act thus considered as unmotivated. And the last character according to Islamic perception, the Prophet Muhammad peace be upon Him as the role model of muslim character. As mentioned by HR.AlBayhaqi, "Behold, Prophet Muhammad has been sent to complete akhlaq (character). "In this research, the researchers would like to investigate three factors that influence the employees' work commitment to the institution of STKIP MPL, namely; interpersonal communication, work motivation, and the employees' characteristics. This to prove whether those factors significantly influence on work commitment of the employee of STKIP MPL and to see which factor is dominant to work commitment.

Some previous studies on this kind of research were conducted by some researchers, such as; Muda, [4], [5] and [6]. Those previous studies have contributed a lot to this research. However, this research has different objectives with the research questions as follow: What factors influence the work commitment of the employee of STKIP Muhammadiyah Pringsewu? Among those factors, which factor has more influence on the employees' work commitment? And how the dominant factor influences the employees' work?

\section{METHOD}

This research was conducted in STKIP Muhammadiyah Pringsewu Lampung, the method used was descriptive qualitative. The population in this study was all the employees of STKIP Muhammadiyah Pringsewu Lampung across various units and divisions. The population of this study comprised a total of 66 from all of the units or division. The sampling technique used in this study was stratified random sampling with the sample size 40. The data collection instrument used was the questionnaire developed by the researcher, especially for this study. The last, the data analysis in this research involves some steps such as; 1) Organizing the data, 2) identifying frame work, 3) sorting the data into framework, 4) using the framework for descriptive analysis, 5) ordering the analysis.

\section{RESULTS AND DISCUSSION}

Three main issues obtained in this research related to the employees' work commitment will be presented in this section based on the data analysis from the result of questionnaire that was given to all the employees of STKIP MPL.

The primary interest on capturing the factors that cause the employees' work commitment is interpersonal communication, 10 questions related to it was given to all respondents. The response from this questionnaire as it is presented in Table I.
Table I. Interpersonal Communication

\begin{tabular}{|c|c|c|}
\hline \multirow{2}{*}{$\begin{array}{l}\text { Interpersonal } \\
\text { communication }\end{array}$} & \multicolumn{2}{|l|}{ Percentage } \\
\hline & $\begin{array}{l}\text { Staff } \\
\text { lecturer }\end{array}$ & Staff \\
\hline Change the subject & $80 \%$ & $85 \%$ \\
\hline $\begin{array}{l}\text { A great deal when someone } \\
\text { disagrees }\end{array}$ & $85 \%$ & $75 \%$ \\
\hline Think clearly when angry & $80 \%$ & $70 \%$ \\
\hline $\begin{array}{l}\text { Discuss without getting } \\
\text { angry }\end{array}$ & $85 \%$ & $80 \%$ \\
\hline $\begin{array}{l}\text { Satisfied with the way } \\
\text { handle difference }\end{array}$ & $75 \%$ & $70 \%$ \\
\hline $\begin{array}{l}\text { Sulk when someone makes } \\
\text { upset }\end{array}$ & $78 \%$ & $75 \%$ \\
\hline Apologize to someone & $80 \%$ & $75 \%$ \\
\hline Admit wrong & $75 \%$ & $70 \%$ \\
\hline Avoid to change the topic & $80 \%$ & $75 \%$ \\
\hline $\begin{array}{l}\text { Continue the conversation } \\
\text { when upset }\end{array}$ & $80 \%$ & $75 \%$ \\
\hline Average & $79.8 \%$ & $75 \%$ \\
\hline
\end{tabular}

The line above shows that the staff lecturer or the lecturers who also have duty as staff have more interpersonal skills comparing to the staff. This happens because staff lecturers always deal with number of students and colleagues personally in daily interaction. [7] Mentioned that interpersonal communication is more personal, the intention in the communication prefers giving and receiving proposals/information involving personal element. Based on the data, in the item of a great deal when someone disagrees and discuss something without angry, the staff lectures seem to be wiser and better than the staff. This takes place because the staff lecturers' main job is teaching students so for handling problem is not difficult for them.

\section{Work motivation}

Work motivation also contributes to the work commitment, the statements in the questionnaire related to motivation has the results as it is presented in Table 2 . Table 2. Work motivation

\begin{tabular}{lll}
\hline Work Motivation & $\begin{array}{l}\text { Percentage } \\
\text { Staff } \\
\text { lecturer }\end{array}$ & Staff \\
& $80 \%$ & $80 \%$ \\
\hline $\begin{array}{l}\text { The achievement } \\
\text { Income received }\end{array}$ & $85 \%$ & $75 \%$ \\
$\begin{array}{l}\text { The incentive received } \\
\text { The authorization received in }\end{array}$ & $80 \%$ & $75 \%$ \\
$\begin{array}{l}\text { satisfying } \\
\begin{array}{l}\text { The authorization in increase } \\
\text { in work spirit }\end{array}\end{array}$ & $70 \%$ & $70 \%$ \\
$\begin{array}{l}\text { The authorization receive } \\
\text { more respectful }\end{array}$ & $85 \%$ & $75 \%$ \\
$\begin{array}{l}\text { Finish the task with team work } \\
\text { Socialize with other } \\
\text { employees }\end{array}$ & $85 \%$ & $80 \%$ \\
$\begin{array}{l}\text { Regard colleagues as the } \\
\text { family }\end{array}$ & $80 \%$ & $75 \%$ \\
\hline Average & $90 \%$ & $85 \%$ \\
\hline
\end{tabular}


From the line above, it can be concluded that both the staff lecturers and staff have great motivation. Yet, the number percentage of the staff lecturers' motivation is higher than the staff. As asserted by [8], work motivation is a set of energetic forces that originates both within as well as beyond an individual's being, to initiate workrelated behaviour, and to determine its form, direction, intensity and duration. In this case, the motivation for being regarded as the family is in the highest position for both staff and staff lecturer.

\section{Character}

Since all the employees of STKIP MPL are Muslim, their working attitudes are based on al-Qur'an and alHadist. The characteristic of Prophet Muhammad SAW also be their model. In line with the vision of STKIP MPL as an excellent and Islamic institution, the employees are demanded to be good Muslim. The questionnaire given to the employees are included to sincerity, trustworthiness, justice, and effort.

Table 3. Islamic Characters possessed by staff and lecturer

\begin{tabular}{|c|c|c|}
\hline \multirow{2}{*}{$\begin{array}{l}\text { Charact } \\
\text { er }\end{array}$} & \multicolumn{2}{|l|}{ Description } \\
\hline & Staff lecturer & Staff \\
\hline Sincerit & In implementing the & working \\
\hline $\begin{array}{l}\text { y and } \\
\text { effort }\end{array}$ & $\begin{array}{l}\text { sincerity character in } \\
\text { effort, the staff } \\
\text { lecturers always work } \\
\text { patiently. The self- } \\
\text { discipline also built in } \\
\text { working along with } \\
\text { truthfulness, gratitude, } \\
\text { honesty, and equity } \\
\text { and justice. All of } \\
\text { those characteristics } \\
\text { are based on forever } \\
\text { mindful of the } \\
\text { almighty-piety. }\end{array}$ & $\begin{array}{l}\text { atmosphere, the } \\
\text { sincerity and } \\
\text { effort built by the } \\
\text { staff. The staff } \\
\text { also always work } \\
\text { based on forever } \\
\text { mindful of the } \\
\text { almighty-piety, } \\
\text { self-discipline, } \\
\text { truthfulness, } \\
\text { gratitude, honesty, } \\
\text { and equity and } \\
\text { justice. }\end{array}$ \\
\hline $\begin{array}{l}\text { Trustw } \\
\text { orthine } \\
\text { ss and } \\
\text { Justice }\end{array}$ & $\begin{array}{l}\text { The trustworthiness } \\
\text { and justice always kept } \\
\text { by the staff lectures in } \\
\text { the working activities, } \\
\text { by promise keeping, } \\
\text { dedication, } \\
\text { responsibility and } \\
\text { transparency }\end{array}$ & $\begin{array}{l}\text { Similar to the staff } \\
\text { lecturer, in } \\
\text { working, the staff } \\
\text { also keep the } \\
\text { trustworthiness } \\
\text { and justice by } \\
\text { promise keeping, } \\
\text { dedication, } \\
\text { responsibility and } \\
\text { transparency }\end{array}$ \\
\hline
\end{tabular}

All of the characters of the staff lecturers and staff above are based on the self-awareness as the Muslim which is guided by al-Qur an and al-Hadist. As recited in al-Qur-an 68: 4 "And indeed, you are of a great character. Thus, in working, the staff lecturer and staff follow the noble character of Prophet Muhammad peace be upon Him. This is in line with the pillars of Muhammadiyah higher education, namely the implementation of Al-Islam and Muhammadiyah in every aspect of life.
To sum up, the research finding shows that interpersonal communication, work motivation, and the employees' character influence the work commitment of the employees of STKIP MPL. From those factors, work motivation gives more influence than interpersonal communication. In addition, character is the dominant factors on the employees' work commitment, which cover both of motivation and interpersonal communication.

\section{REFERENCES}

[1] Kreitner, Robert and Angelo Kinicki. Organizational Behavior. New York: McGraw Hill.2007.

[2] Vorster,C. IMPACT The Story of Interactional Theraphy. Pretoria:SAT. 2011.

[3] Deci, L.E \& Ryan, R. Intrinsic and Extrinsic Motivations; classic definition and new directions. Contemporary Educational Psychology, (25), 5467. 2000.

[4] Mudam Rafiki and Harahap. Factors Influencing Employees' Performance: A Study on the Islamic Banks in Indonesia. International Journal of Business and Social Science. Vol.5.No.2; February 2014.

[5] Hussain, et.al (2012) Factors Affecting the Job Performance; In case of Pakistani Banking Sector. Elixir International Journal. Volume 47 (2012) 8726-8730.

[6] Schulze, S. 2006. Factors Influencing the Job Satisfaction of Academics in Higher Education. SAJHE 20 (2) 2006 pp.318-335

[7] Sirait, J. The Effect of Interpersonal Communication, School Organization Culture, Job Satisfaction and Work Motivation to Organizational Commitment of the State Primary School Principals in North Tapanuli District. International Journal of Sciences; Basic and Applied Research (IJSBAR). Volume 25, No. 1,pp 363-388.2016.

[8] Tremblay, M.A. et.al. Work Extrinsic and Intrinsic Motivation Scale: Its Value for Organizational Psychology Research. Canadian Journal of Behavioral Science. 2009, Vol.41, No. 4,213-226. 